\title{
BUDOUCNOST ŠKOLY V PERCEPCI ŠKOLSKÉHO MANAGEMENTU
}

\author{
KAREL ČERNÝ
}

\begin{abstract}
Abstrakt: Studie pojednává o empirickém výzkumu percepce budoucnosti školy a vzdèlávání a vychází z dotazníkového šetřenímezi školským managementem. Částečně navazuje na již provedená domácí i zahraniční šetření (ověrování scénářu budoucnosti školy OECD, delfská studie LEONIE). Studie se zaměřuje na tyto oblasti: budoucnost školy, klíčoví aktéři a klíčové problémy, hodnocení důležitosti celospolečenských trendů pro budoucnost školy a vzdělávání a jednotlivých opatření vzdělávací politiky.
\end{abstract}

Klíčová slova: budoucnost, škola, vzdělávání, školský management, dotazníkové šetření, scénáre, trendy

Abstract: The study focuses on school manager's perception of the future of schooling. The evidence is based on a social survey which was partly inspired by domestic as well as international surveies (like testing OECD scenarios, Leonie Delphi survey). The study particularly deals with this items: perception of the school for the future, key actors and key problems, evaluation of social trends with impact on school and education and educational policy strategie.

Key words: future, school, education, school management, social survey, scenarios, trends

\section{1. Úvod: Co bylo předmětem výzkumu a koho jsme se ptali?}

Empirický výzkum školských managerů byl zaměřen na různé aspekty dimenze budoucnosti školy a vzdělávání, přitom se svým zaměřením koncentroval na primární a nižší sekundární stupeň vzdělávání (samozřejmě s přesahy do vyšších stupňů). Všímal si následujících vzájemně souvisejících okruhů: (1) hodnocení pravděpodobnosti a žádoucnosti jednotlivých alternativních scénářu budoucnosti školy, (2) percepce důležitosti jednotlivých znalostí, dovedností, hodnot a postojů, na které by měly školy v 21. století klást důraz, včetně hodnocení oblastí, kde je aktuálně pocitován největší „deficit", (3) hodnocení významu jednotlivých aktérů, kteř́ ovlivňují podobu a směřování školy, a problémů, které rozvoj školy naopak limitují, (4) hodnocení vlivu celospolečenských trendů ovlivňujících vzdělávání a také hlavních trendů probíhajících na úrovni vzdělávacího systému, (5) hodnocení pravděpodobnosti a přiměřenosti opatření vzdělávací politiky v př́štích 10 letech. 
Celkově je tedy následující text rozdělen do dvou logicky navazujících částí: nejprve se zaměřuje na budoucnost školy a školního vzdělávání - scénáře a zvláštní zřetel na kompetence - $v$ druhé části se pak podrobně věnuje percepci široké škály faktorů, které toto budoucí směřování školy a školního vzdělávání ovlivňují.

Výzkum se do značné míry inspiroval (a navazoval) již provedenými mezinárodními i domácími výzkumy. Zejména ověřováním scénářů budoucnosti školy (Hutmacher 2001, Kotásek 2004a) a evropským projektem LEONIE zaměřeným na zkoumání trendů ovlivňujících školu a vzdělávací systémy, ale také domácími výzkumy veřejného mínění zabývajícími se vztahem široké i odborné veřejnosti ke školství (např. AMD 1995, AMD 1996). Cílem tohoto příspěvku tedy není jen deskripce percepce budoucnosti školy a školního vzdělávání, ale také pokus o komparaci s již provedenými výzkumy, ačkoliv tato srovnání mohou být pouze omezená s ohledem na limity používaných dat (viz dále).

Respondenti se rekrutovali $z$ řad studentů bakalářského kombinovaného studia v oboru Školský management. Dotazníky byly administrovány v rámci kurzu Vzdělávací politika a školské systémy na PedF UK v roce 2006, přičemž otázky kladené v dotazníku měly přímou vazbu na problémové okruhy, koncepce a odbornou terminologii podrobně probíranou v tomto kurzu. Výběrový soubor tedy nebyl pořízen prostým náhodným výběrem, nýbrž nenáhodným záměrným výběrem na dostupném vzorku. Jelikož nejde o reprezentativní soubor, charakter dat neumožňuje vyvozovat generalizované závěry, které by spolehlivě platily pro celou populaci školských manažerů. Nicméně se domníváme, že získané informace mohou napovědět mnohé o postojích a názorech jedněch z významných aktérů, kteří ovlivňují podobu školy - a tedy i směřování českého školství - v 21. století.

Na výzkumu participovalo celkem 76 respondentů, návratnost dotazníků vysoce přesahovala $90 \%$ (což bylo dáno specifickým charakterem výzkumu). Nejvýrazněji byli zastoupeni pracovníci zodpovědní za vedení školy - ředitelé (51\%) či zástupci ředitele (9\%). Učitelé tvořili druhou nejpočetnější skupinu ( $25 \%$ ), většina z nich se však připravovala na pozici vedoucích pracovníků. Ve vzorku jsou výrazně nadproporčně zastoupeni respondenti profesně působící na úrovni preprimárního vzdělávání (MŠ), ti tvoří celkem $46 \%$ výběrového souboru (primární stupeň: $18 \%$, sekundární stupeň $27 \%$ ).

Z hlediska dalších socio-demografických charakteristik výběrového souboru je nutno uvést vyšší zastoupení žen (79\%) oproti mužům (21 \%), což je v souladu s poznatky o feminizaci - zejména nižších stupňů - českého školství, která pak sahá i do vyšších pozic na úrovni řízení školy. Důležité je zdůraznit, že se respondenti rekrutovali prakticky ze všech regionů České republiky. Také kontrola zastoupení z hlediska sídelní struktury (dle velikosti místa působiště) ukázala, že v našem vzorku jsou jak respondenti z malých obcí, tak i ze středních a velkých měst. 


\section{Scénáře školy budoucnosti: pravděpodobný versus žádoucí vývoj}

První okruh dotazování se soustředil na dvě otázky. Jaký model školy budoucnosti je školskými managery považován za nejpravděpodobnější? A jaký scénář je naopak vnímán jako nejvíce žádoucí - jako ideální model školy pro 21. století?

$\checkmark$ obecné rovině Ize říci, že na půdě $O E C D$ vypracované scénáře ${ }^{1}$ budoucnosti školy umožňují položit si otázku po pravděpodobnosti, stejně tak i žádoucnosti každého z nich (nejde tedy ani o čistou predikci, avšak ani pouze o normativní vizi). Časovým horizontem, ke kterému se vztahují, je období přístích cca 15-20 let - toto vymezení přesahuje obvyklé vládní cykly vzdělávací politiky, aniž by však upadalo do nadměrné spekulativnosti. Relativní obecnost a nekonkrétnost jednotlivých scénářu je dána tím, že se snaží obsáhnout podobu školských institucí od předškolního vzdělávání až po vyšší sekundární. Představme si nyní ve stručnosti šest alternativních modelů budoucího vývoje školy (scénáře podle Kotásek 2002, 2004a, OECD 2001):

\section{EXTRAPOLACE SOUČASNÉHO STAVU}

Tradiční model veřejné školy a udržování silných byrokraticky řízených školských systémů - scénář předpokládá, že dosavadní školské systémy se silnými prvky byrokracie a tlakem k uniformitě přetrvají i do budoucna, nebudou riskovat radikální změny a zachovají tradiční model školy a výuky do značné míry v takové podobě, jako ho známe doposud.

Krizový model školy jako důsledek odlivu zájmu o učitelskou profesi. Krize učitelské profese se projevuje alarmujícím stárnutím pedagogických sborů. Nedostatek mladých učitelů a neschopnost škol mladé kantory udržet je způsoben jednak nízkou přitažlivostí učitelské profese, která stále hưře konkuruje s nově vznikajícími atraktivními pracovními přiležitostmi (ve službách, médiích, kultuře aj.), jednak zvyšujícím se zatížením a náročností pedagogické práce, ale i pravděpodobným poklesem celkové společenské prestiže učitelư. Výsledkem bude zpomalení či zastavení inovačních procesů na školách a celkové snížení kvality vzdělávání.

Prípadná zásadní opatření vzdělávací politiky se projeví s dlouhým časovým odstupem, dynamika scénáře vykazuje výrazné pozitivní zpětné vazby urychlující

1 Scénáře-"příběhy o možných (alternativních) budoucnostech"- se řadí k základním procesuálním prognostickým metodám, přičemž kladou důraz na kvalitativní metodologii. Užívají se v prípadech, kdy je potřeba současně zohlednit mnoho faktorů (pro danou oblast relevantních hybných sil), kdy panuje poměrně vysoký stupeň nejistoty ohledně budoucího stavu a kdy nemůže být minulost ani prítomnost spolehlivým vodítkem pro budoucnost. Jejich ambicí proto nejsou jednoznačné předpovědi budoucnosti, nýbrž popis možných budoucích událostí a trendů na základě alternativních předpokladů (deskriptivní scénáře), případně popis možností dosažení žádoucího budoucího stavu (normativní scénáře). Dobře zpracované scénáře by měly být nejen hodnověrné a vnitřně konzistentní, ale také inspirativní - měly by sloužit jako podnětný zdroj soustavného uvažování o možných budoucnostech (podle Nekolová 2006). 
další odliv učitelů. Významným rozměrem krizového scénáře je riziko prohloubení regionálních (krize poskytne některé regiony více, jiné méně) a sociálních (lépe situované rodiny budou hledat východisko v soukromém školství, intenzivnějším využívání ICT aj.) nerovností.

\section{RESCHOLARIZAČNÍ SCÉNÁŘE}

Komunitní model školy - předpokladem tohoto scénáře, stejně jako v prípadě modelu učící se školy, je široký společenský konsenzus (zde klíčová role vzdělanějších sociálních skupin a médií) ohledně významu školního vzdělávání jako nejúčinnějšího nástroje proti sociální fragmentaci a ztrátě společenských hodnot. Ten je však provázen i přislušným přesměrováním finančních tokủ. Škola se v tomto pojetí stává hlavním střediskem společenského života obce (typické jsou intergenerační aktivity včetně celoživotního vzdělávání), status učitele se posiluje.

Model učící se školy odpovídá potrebám rozvíjející se společnosti vědění a ekonomiky založené na znalostech. Kritickým předpokladem je otevřenost učitelstva k novým prístupům a metodám, zvýšená inovativnost institucí profesní přípravy i dalšího vzdělávání učitelů. Škola funguje jako „učící se organizace“ zaměřená na permanentní vnitřní zdokonalování s klíčovou rolí týmové práce pedagogů a vysokých manažerských nároků kladených na personál. Typická je specifická profilace jednotlivých škol, důraz na vysokou kvalitu a šíri nabídky, personalizace vzdělávacích procesů šitých na míru jednotlivým žákům. Zvýšená pomoc bude věnována zaostávajícím žákům, utváření ročníků, tříd a učebních skupin bude výrazně variabilnější a výraznější roli bude hrát také experimentování. Mezi jednotlivými školami, ale i dalšími "učícími se organizacemi", se vytvoří sít vazeb, které budou stimulovat další inovace. Předpokládá se zachování silné podpưrné role centrálních státních struktur se zvláštním zřetelem na pomoc nejslabším školám.

\section{DESCHOLARIZAČNÍ SCÉNÁŘE}

Model učebních sítí - předpokladem scénáře je nespokojenost (rodičovské) veřejnosti s tradiční podobou školy, která se stává stále více nevyhovující tváří v tvář novým požadavkům. Rozvoj a šiření nových médií a technologií (např. internetu) zároveň umožní radikální deinstitucionalizaci učení - ve své krajní podobě by mělo podobu začleňování „izolovaného“ individua do učebních sítí v podmínkách informační společnosti sítí, kde se však má uplatnit spolupráce více než konkurence jednotlivých subjektů. Učení by se tak neuskutečňovalo v prostorově a časově vymezeném místě (,„̌kola“) a s pomocí „,učitelư“. Zásadní roli by hráli rodiče v podmínkách domácího vzdělávání a také informální učení. Je zřejmé, že by došlo k oslabení role státu. Krom toho je také reálné riziko sociálního vylučování těch, kteří nemají dostatečný prístup k sítím.

Tržní model školy se bude prosazovat $v$ důsledku nespokojenosti až revolty daňových poplatníků s úrovní veřejného školství a šíření neoliberální ekonomické rétoriky prosazující zavádění zásad tržní konkurence, deregulace, manažerských pří- 
stupů a privatizace i v oblasti školství a vzdělávání. Vznikne jakási duální struktura privátního a veřejného školství a poskytovatelů vzdělávání s různou mírou průniku a spolupráce soukromých a veřejných aktérů. Je zřejmé, že celková role centrálních orgánů bude spíše upadat a konkurence mezi poskytovateli vzdělávání bude mít tendenci potlačovat vzájemnou kooperaci. Vzdělávací dráhy tak budou značně individualizované.

\subsection{Jaký vývoj školy jejich management očekává?}

Pro toto šetření byla použita obdobná metodika (dotazníková metoda se čtyřstupňovou škálou $s$ jejíž pomocí se hodnotila jak pravděpodobnost, tak také žádoucnost daného scénáře), která již byla využita při zahraničním i domácím ověřování a posuzování scénářủ budoucnosti školy, a to na obdobně velkém, nenáhodně zvoleném vzorku respondentů (viz Kotásek 2004a, Hutmacher 2001).

Celkem šest alternativních scénářu výše nastíněných vychází ze tří možných základních trendů: (1) zachování a prodloužení současného stavu (extrapolace neboli status quo extrapolated) - sem spadá tradiční byrokratický model a scénář rozšiǐování tržního modelu, (2) rozvoj a posílení funkcí školy (rescholarizace) - komunitní scénář a model učíí se školy, (3) omezení a oslabování postavení školy (descholarizace) - model učebních sítí a scénář krizový.

Faktorová analýza naznačuje, že respondenti chápou jako vzájemně si blízký - at' již u otázky na pravděpodobný či žádoucí model vývoje - scénář komunitní a učící se školy. To odpovídá představě s jakou se scénáŕi pracují experti OECD: jde o skupinu rescholarizačních scénářư založených na posilování funkcí školy. Jako další skupinu (faktor) však naši respondenti chápou tržní model školy spolu s modelem učebních sítí; tyto dva modely dotázaní pokládají za vzájemně si blízké scénáře budoucího vývoje. Ačkoliv původní logika autorů scénářu (viz výše, srov. OECD 2001, Kotásek 2002) hovořila o tom, že tržní model školy patří ke skupině „extrapolace současného stavu" a model učebních sítí naopak do skupiny descholarizační - oslabování funkcí školy - dnes mezi experty vzniká konsenzus, který řadí oba tyto scénáře do množiny descholarizačních modelů (srov. Greger 2006, s. 47). Tím vlastně dochází ke sbližování pohledů našich respondentů a analytiků OECD. V př́padě tradičního byrokratického modelu a scénáře krizového však naši respondenti nevidí jakékoliv jejich přiřazení do společné skupiny dalších scénářů a chápou je spíše jako samostatné modely.

$\checkmark$ prípadě hodnocení pravděpodobného vývoje školy v přištích desetiletích panuje relativně vysoká nerozhodnost, nejistota a nejednoznačnost - vyšší než v případě představ týkajících se ideální podoby školy (viz dále). Naprostá většina respondentů (mezi 80 a $90 \%$ ) volila při hodnocení jednotlivých scénářů "opatrnou"

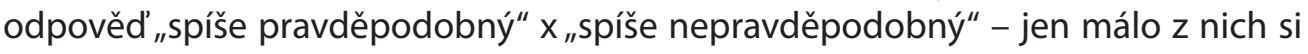

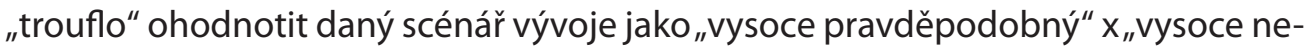
pravděpodobný“. Podobně i v již provedených výzkumech se projevovala obdobná nejistota ohledně budoucnosti školy (srov. Kotásek 2004a, s. 470). 
S nejednoznačným názorem na budoucí vývoj školy souvisí zjištění, že žádný scénář budoucího vývoje školy není chápán jako jednoznačně pravděpodobnější než scénáře ostatní, přičemž žádný ze scénářů nezískal znatelnou - výrazně nadpoloviční - podporu (viz tabulka č. 1).

Jako mírně pravděpodobnější se jeví modely založené na předpokladu budoucího posilování funkcí školy (rescholarizace) - tedy komunitní a učíí se modely školy. I tak je ale hodnotí jako "vysoce/spíše pravděpodobné" pouze zhruba polovina respondentů.

Stejně pravděpodobně jsou však hodnoceny také tradiční byrokratický model školy (extrapolace současného stavu) a scénář krizového vývoje této instituce (descholarizace). Za pravděpodobné je pokládá opět asi polovina respondentů. Znepokojivá je zejména vysoká obava vedení škol z vývoje směrem ke krizovému scénáři provázenému stárnutím pedagogických sborů a „exodem“ mladých a schopných pedagogů mimo školství.

Jako spíše nepravděpodobný směr vývoje je chápán tržní scénář školy, stejně tak i trend ke vznikání sítí žáků učících se v podmínkách společnosti sítí (za pravděpodobné pokládá asi třetina dotázaných), které nejsou chápány jako realistický směr vývoje.

Přibližně podobných výsledků (viz tabulka č. 1) bylo dosaženo v mezinárodním šetření $(N=73)$ mezi delegáty mezinárodní konference $O E C D$ o školských inovacích (2000), kde převažovali zástupci decizní sféry, výzkumníci a experti. Jako mírně pravděpodobnější v horizontu příštích 15-20 let se také zde - a dokonce o něco jednoznačněji - jeví rescholarizační scénáře: modely komunitní a učící se školy. Lze tedy snad opatrně konstatovat, že zahraniční respondenti rekrutující se z řad exekutivy a špičkových výzkumníků mají oproti českým respondentům s přímou zkušeností $z$ vedení škol tendenci být poněkud "optimističtějši” ohledně hodnocení budoucnosti školy (viz hodnocení rescholarizačních scénářu jako pravděpodobnějších).

Oproti tomu v české sondě z roku 2002 (též $N=73$ ) - podobně $i$ jako v sondě z roku 2001 - provedené ve skupině svým složením velmi blízké našemu šetření (ředitelé škol s malým podílem doktorandů) se ukázalo, že za nejpravděpodobnější jsou pokládány scénáře počítající s extrapolací současného stavu do budoucnosti. Jako jednoznačně nejreálnější byl chápán tradiční model školy ( $90 \%$ respondentů pokládá za pravděpodobný směr vývoje) následovaný tržním modelem školy (70\% respondentů). Až poté následují scénáře ze skupiny rescholarizační počítající s posilováním funkcí školy - model komunitní či učící se školy. Jelikož ani jeden z komparovaných domácích souborů není reprezentativní, o vývoji či dynamice percepce budoucnosti školy v čase (rok 2002 a 2007), Ize vynášet jen omezené a opatrné závěry. Za nejdůležitější lze zmínit tendenci k vyšší míre obav ohledně vývoje směrem ke krizovému scénáři (v r. $200222 \%$ respondentů, r. 2007 již 55 \%). 
Tab. 1. Percepce scénářů budoucí školy: pravděpodobné vs. nepravděpodobné modely

\begin{tabular}{|l|c|c|c|}
\hline & $\begin{array}{c}\text { Management } \\
2007\end{array}$ & $\begin{array}{c}\text { Hutmacher } \\
2000\end{array}$ & $\begin{array}{c}\text { Česká sonda } \\
2002\end{array}$ \\
\hline tradiční model školy & 55 & 56 & 90 \\
krizový model školy & 55 & $\mathrm{n}$ & 22 \\
komunitní model školy & 49 & 59 & 59 \\
model učící se školy & 54 & 63 & 57 \\
učební sítě & 36 & 47 & 38 \\
tržní model školy & 36 & 47 & 70 \\
\hline
\end{tabular}

(\% odpovědí „spíše/vysoce pravděpodobný" scénář)

\subsection{Jaké jsou představy o ideální škole budoucnosti?}

Pokud jde o názor na ideální podobu školy, zde jsou již postoje zformovány jasněji a vyhraněněji než v prípadě hodnocení pravděpodobného vývoje - dotazovaní se zdaleka tolik "neuchyluji“" ke středním kategoriím („spíše žádouci“"/"spíše nežádouci"), častěji dávají přednost vyhraněnějším stanoviskưm. Navíc se mezi nimi rýsuje jasný konsenzus v tom, jaké scénáře jsou žádoucí "favorité" školy budoucnosti - a jaké naopak nechtění „outsideři".

Zřetelným „favoritem“ jsou rescholarizační scénáře školy: modely komunitní a učící se školy získaly „sympatie“ více než 90 \% respondentů z řad školského managementu. Podobné názory byly pozorovány také v české sondě z roku 2002, stejně tak i v mezinárodním šetření v roce 2000 (viz tabulka č. 2).

Oproti tomu jasnými „outsidery“ se staly tradiční byrokratický model školy, tedy model, který nejlépe odpovídá současné situaci. Preferuje jej asi desetina dotázaných školských managerů. Podle očekávání patří mezi „outsidery“ také krizový scénář školy (tady se spíše nabízí otázka, kdo a proč takový scénář vůbec preferuje).

Zhruba pětina respondentů - působících ve veřejném školství - chápe jako ideální scénář také tržní model školy.

Tab. 2. Percepce scénářů budoucí školy: žádoucí vs. nežádoucí modely

\begin{tabular}{|l|c|c|c|}
\hline & $\begin{array}{c}\text { Management } \\
2007\end{array}$ & Hutmacher 2000 & $\begin{array}{c}\text { Česká sonda } \\
2002\end{array}$ \\
\hline tradiční model školy & 12 & 27 & 53 \\
krizový model školy & 5 & $\mathrm{n}$ & 11 \\
komunitní model školy & 93 & 82 & 93 \\
model učící se školy & 96 & 85 & 91 \\
učební sítě & 60 & 52 & 29 \\
tržní model školy & 21 & 21 & 41 \\
\hline
\end{tabular}

(\% odpovědí "spíše/vysoce žádoucí" scénář) 
„Futurologický“ model sítí učících se žáků považuje za žádoucí více než polovina dotázaných (60\%), což je poměrně překvapivý výsledek vzhledem $\mathrm{k}$ tomu, že ve srovnatelných domácích šetřeních (v letech 2001 a 2002) se podobné podpory danému scénáŕi nikdy nedostalo.

\section{Znalosti, dovednosti, postoje a hodnoty pro 21 . století}

Poté, co jsme se zabývali percepcí institucionální podoby školy budoucnosti, se nyní zaměřme na to, co by se $v$ takovéto škole mělo podle našich respondentů učit. Soustřed'me se na dva okruhy otázek: (a) jaké znalosti, dovednosti, postoje a hodnoty by měly základní školy s ohledem na požadavky 21 . století rozvíjet, (b) jaké z nich současné školy nerozvijí dostatečně, tj. kde je pocitován největší deficit. Přitom jsme se koncentrovali na úroveň základní školy. Důležitost kompetencí, hodnot či postojů by se tedy zcela jistě lišila, vztahoval-li by se předložený seznam položek k vyššímu sekundárnímu či dalším vzdělávacím stupňům.

Žádná z 28 hodnocených znalostí, dovedností, postojů a hodnot není respondenty chápána jako nedůležitá či irelevantní. Všechny jsou naopak pokládány za důležité - na škále jsou odpovědi distribuovány nejčastěji mezi kategorií "rozhodně důležité" a „spíše důležité". Základní školy by je tedy podle respondentư měly u žákư rozvíjet všechny, odlišnosti mezi položkami plynou pouze z míry jim přikládaného významu vzhledem k výzvám 21. století.

Velké množství jednotlivých položek (tj. 28) Ize za účelem zpřehlednění s pomocí faktorové analýzy přiřadit do osmi základních množin znalostí, dovedností, postojů a hodnot, jejichž prvky (rozuměj položky) respondenti chápou jako vzájemně si blízké. Toto členění tedy nemusí odpovídat klasifikaci v pedagogice, jde spíše o postižení toho, jakým způsobem o problému uvažují sami respondenti. Faktory jsou seřazeny podle důležitosti, jež je jejich položkám připisována.

Jako nejdůležitější se ukázal faktor základů pro další studium "sycený" těmito položkami: naučit se učit, tj. kompetence pro ř́zení vlastního učení, získat základ pro další studium, umět logicky myslet a být samostatný, umět se rozhodovat.

Jako neméně důležitý a úzce související se jeví další faktor, který je tvořen jedinou samostatnou položkou: chut' a motivace do dalšího studia. Jestliže první faktor se týká kompetencí, jakýchsi „všeobecných studijních předpokladů“, ve druhém faktoru jde spíše o formování motivačních či afektivních složek osobnosti. Základní škola je tedy především chápána jako „odrazový“ můstek pro další (celoživotní) učení, nikoliv jako místo, kde by se měl klást primární dưraz na znalosti a dovednosti vázané na konkrétní vyučovací předměty.

Faktor etických postojů a morálního usuzování velmi silně spjatých s tím, co jedince časově přesahuje, transcenduje, at již směrem do minulosti či budoucnosti: rozvoj etických postojů, morálního usuzování, rozvoje postojů k české historii, národu a jeho hodnotám, výchova pro trvale udržitelný rozvoj (ekologická výchova).

Faktor kvality života: mít vztah ke kultuře, umění, naučit se zdravě žít. 
Faktor slušného chování a dobrého občanství: zdvořilost, slušné chování, být dobrým občanem (zodpovědnost za věci veřejné).

Dovednosti a postoje pro každodennost. Jde o obecné, nad-předmětové dovednosti a postoje těsně spjaté $s$ uplatnitelností v každodenním praktickém životě mimo školu: schopnost kritického myšlení, smysl pro kvalitu odváděné práce, umění jednat s lidmi z různých vrstev, schopnost týmové práce, sebedůvěra, kreativita a tvořivost.

$S$ poněkud větším odstupem končí naše klasifikace posledními dvěma faktory, jež jsou respondenty chápány jako relativně méně důležité než ostatní. Základní škola by na ně tedy podle nich měla klást menší důraz než výše uvedené faktory. Faktor základních znalostí a dovedností těsně svázaných s konkrétním vyučovacím předmětem (či skupinou předmětů). Sem patří: dovednost získat základy pro využívání výpočetní techniky, ovládnutí základních numerických operací (práce s grafy, čísly, schématy), dále základy pro komunikaci v cizích jazycích či schopnost vyjadřování v písemném i ústním projevu, konečně také schopnost čtení s porozuměním. Důležitost těchto „předmětových“ znalostí a dovedností by byla patrně hodnocena jako významnější v prípadě středního školství.

Jako z hlediska základní školy nejméně důležitý je důraz na znalosti a postoje pro život $\mathbf{v}$ „nadnárodním kontextu“. Tyto položky jsou z hlediska základní školy chápány patrně jako „odtažitějši“" či „předčasné" ve srovnání s ostatními položkami z předložené baterie. Jejich důležitost by nejspišs vzrostla při posuzování vyšších vzdělávacích stupňů: rozumět životu v jiných zemích, vědomí širších evropských souvislostí a formování postojů k evropským hodnotám, schopnost uvažovat v globálním kontextu, včetně globální zodpovědnosti a konečně kompetence pro soužití $v$ multikulturní společnosti. Zde je však na místě opět připomenout, že ani poslední dva faktory nejsou školskými managery chápány jako nedůležité v absolutním slova smyslu, také ony jsou respondenty chápány nejčastěji jako „spíše důležité“.

Kompletní výčet posuzovaných položek a jejich pořadí z hlediska subjektivně posuzované důležitosti Ize nalézt v tabulce č. 3 . Celkově lze výsledky shrnout tak, že největší důraz není pocitován v oblasti konkrétních oborových či předmětových znalostí a dovedností, základní škola by se podle respondentů měla soustředit v prvé řadě na rozvoj obecných předpokladů pro další (celoživotní) vzdělávání, které základní školou nekončí, nýbrž začíná. Respondenti však neméně silně zdůrazňuji také občanské a etické postoje a "dobré mravy". 
Tab. 3. Na co by měla základní škola pro 21 . století klást důraz?²

\begin{tabular}{|l|l|}
\hline & Průměr \\
\hline naučit se učit (kompetence k řízení vlastního učení) & 1,13 \\
\hline být samostatný, umět se rozhodovat & 1,14 \\
\hline být dobrým občanem (zodpovědnost za věci veřejné) & 1,16 \\
\hline Zdvořilost, slušné chování & 1,16 \\
\hline rozvoj etických postojů, morálního usuzování & 1,21 \\
\hline mít sebedůvěru & 1,21 \\
\hline chut' a motivace do dalšího studia & 1,22 \\
\hline umět se vyjadřovat (písemný i ústní projev) & 1,24 \\
\hline Schopnost čtení s porozuměním & 1,24 \\
\hline základy pro komunikaci v cizích jazycích & 1,24 \\
\hline smysl pro kvalitu odváděné práce & 1,24 \\
\hline naučit se zdravě žít & 1,25 \\
\hline výchova pro trvale udržitelný rozvoj (ekologická výchova) & 1,28 \\
\hline postoje k české historii, národu a jeho hodnotám & 1,29 \\
\hline Schopnost týmové práce & 1,34 \\
\hline Schopnost kritického myšlení & 1,34 \\
\hline umět logicky myslet & 1,35 \\
\hline mít vztah ke kultuře, umění & 1,35 \\
\hline kreativita a tvořivost & 1,37 \\
\hline získat základ pro další studium & 1,40 \\
\hline umět jednat s lidmi z různých vrstev & 1,41 \\
\hline kompetence pro soužití v multikulturní společnosti & 1,49 \\
\hline získat základy pro využívání výpočetní techniky & 1,50 \\
\hline Všeobecný přehled, základní znalosti různých oborů & 1,59 \\
\hline Schopnost uvažovat v globálním kontextu, globální zodpovědnost & 1,75 \\
\hline rozumět životu v jiných zemích & 1,76 \\
\hline Ovládnout základní numerické operace (práce s čísly, grafy, schématy) & 1,78 \\
\hline vědomí širších evropských souvislostí, postoje k evropským hodnotám & 1,79 \\
\hline PRŮměR & $\mathbf{1 , 3 6}$ \\
\hline Pruměn skóre jedno & \\
\hline
\end{tabular}

(Průměrné skóre jednotlivých položek, řazeno vzestupně - od nejdůležitějších k nejméně důležitým)

2 Respondenti hodnotili každou z 28 položek na přiložené čtyřstupňové škále nabývajících hodnot 1 až 4. Přitom ani jedna z hodnocených položek nebyla souborem respondentů chápána jako pro 21. století nedůležitá (at již „spiše“ či „rozhodně“). Pro orientační rozlišení mezi položkami, které jsou chápány jako relativně důležitější než jiné, byl proto použit průměr důležitosti všech položek (viz 1,36). Znalosti, dovednosti, postoje či hodnoty, které nabývají nižších průměrných hodnot než 1,36, jsou tedy chápány jako relativně důležitější než ty, které nabývají průměrů vyšších (viz čára dělící tabulku). Tím však nelze říci, že by je respondenti chápali jako nedůležité (i tyto „nedůležité“ položky jsou ve svém průměru chápány jako „spiše“" důležité. 
A v jakých oblastech je pocitován největší deficit současné školy? České základní školy podle vedení škol zaostávají zejména v těchto oblastech: schopnost uvažovat v širším celoevropském či dokonce globálním kontextu, kompetence pro soužití v multikulturní společnosti, schopnost kritického myšlení, kreativity a tvořivosti, schopnost týmové práce a dovednost jednat s lidmi z různých společenských vrstev. Vidíme tedy, že největší deficit je pocitován ve dvou skupinách znalostí, dovedností, hodnot a postojů: ve faktoru znalostí a dovedností pro život v „nadnárodním kontextu" a ve faktoru obecných a nad-předmětových dovedností pro uplatnění v každodenním životě.

Naopak se škole podle názorů jejich vedení daří bez problémů rozvíjet zejména tyto znalosti, dovednosti či postoje: vytvoření základů pro využívání výpočetní techniky, základy pro další studium, všeobecné znalosti z různých oborů, schopnost čtení s porozuměním, základní numerické operace, ale i základy cizích jazyků nebo znalosti a postoje spjaté s výchovou pro trvale udržitelný rozvoj (ekologická výchova). Jako bezproblémová je tedy viděna zejména oblast základních znalostí a dovedností těsně spjatých s konkrétními vyučovacími předměty.

Srovnáme-li tyto výsledky s výzkumem veřejného mínění z poloviny 90 . let (AMD $1995)^{3}$, reditelé oproti široké veřejnosti kladli větší důraz zejména na tyto položky: být zdvorilý a chovat se slušně, být dobrým občanem, mít vztah ke kultuře a umění či naučit se zdravě žít. Oproti tomu široká laická veřejnost (se zastoupením rodičovské populace) kladla oproti vedení škol větší důraz pouze na dva momenty: získat základ pro další studium a umět logicky myslet. Jestliže tedy ředitelé kladou větší důraz na etické a kulturní aspekty školního vzdělávání se zřetelem na jeho širší společenské funkce, laická veřejnost zdůrazňuje spíše „praktickou“ stránku s důrazem na individuální kariéru a uplatnění ${ }^{4}$.

\section{Klíčoví aktéři: kdo určuje podobu školy?}

Z celkem 16 posuzovaných aktérů, kteří mají možnost ovlivňovat podobu základní školy (a tedy i její budoucí směřování ve smyslu hlavních nastíněných scénářů), byly nejprve s cílem zjednodušení a zpřehlednění dat za pomoci faktorové analýzy určeny hlavní skupiny aktérů. Ty jsou respondenty chápány jako př́buzné, vzájemně si blízké, subjekty - a tedy spadající do stejné „množiny“ (faktoru). Bylo jim přisouzeno následující zobecňující pojmenování:

(1) faktor "lidských zdrojů“ školy (zejména ředitelé a učitelé),

(2) faktor centrálních státních orgánů (Parlament ČR, Vláda ČR, MŠMT),

(3) faktor vnějších institucí poskytujících škole odbornou expertízu, dohled a/ nebo dodatečné zdroje (Evropská unie, školní inspekce, odborníci a experti v problematice vzdělávání aj.),

3 V tomto výzkumu byla položena baterie s 16 položkami, proto lze porovnávat pouze ty, které byly zařazeny do obou výzkumů. Srovnávána jsou \% odpovědí „rozhodně ano“.

4 Zde je nutné uvést, že ve výzkumu veřejného mínění byla otázka položena bez konkrétního vymezení vzdělávacího stupně, kterého se týká, kdežto ve výzkumu školského managementu jsme se ptali na to, co by měly rozvíjet základní školy. Neptali jsme se tedy na zcela totožnou věc. 
(4) občanská společnost v nejširším slova smyslu (nevládní neziskové organizace, rodiče a jejich organizace, církve, žáci a jejich samosprávy aj.),

(5) odbory (jako samostatný faktor).

Směřování školy může podle školských manažerů samých ovlivnit zejména školský management, tedy ředitelé škol. Jako "velmi výrazně/výrazně" důležité pro rozvoj školy je hodnotí $97 \%$ dotazovaných. Mezi respondenty navíc v tomto ohledu panuje největší konsenzus (viz nízká hodnota směrodatné odchylky). Jako podobně zásadní pro další rozvoj školy je chápán potenciál učitelů (také v tomto ohledu panuje vysoká shoda), za "velmi výrazně/výrazně" důležité je pokládá $93 \%$ dotazovaných. V obou prípadech tedy jde o aktéry působící prímo „V terénu“ na úrovni školy, kteří jsou vyjádřeni faktorem „lidských zdrojů“ školy.

Za nimi se umístily státní (makro)instituce ovlivňující a určující širší rámec, $v$ němž je škola zasazena. Jde o ( $v$ tomto pořadí): ministerstvo školství, parlament a vládu. Jako „velmi výrazně/výrazně“ důležité pro budoucí směřování školy je pokládá přes $80 \%$ respondentů.

Z veřejných institucí jsou vnímány jako poměrně klíčové ještě městské (obecní) úřady $(86 \%)$ a krajské orgány $(75 \%$ respondentů).

Přibližně stejná důležitost je přisuzována rodičům (případně rodičovským organizacím) a žákům samotným. Za "velmi výrazně/výrazně" důležité pro vývoj školy je pokládá $82 \%$, respektive $76 \%$ respondentů.

Zvyšující se role Evropské unie a jejích fondů je respondenty reflektována tou měrou, že její význam je chápán až jako srovnatelný s významem krajských samospráv. Jako "velmi výrazně/výrazně" důležitou z hlediska rozvoje školy hodnotí Evropskou unii ve svých odpovědích plných $80 \%$ respondentů - avšak nutno dotaz, že plných $70 \%$ dotázaných se přiklání k méně vyhraněné odpovědi „výrazně“, nikoliv "velmi výrazně" (zde pouze $10 \%$ ).

Na samém konci žebříčku významnosti aktérů, jejichž vliv dotazovaní vnímají ještě jako alespoň trochu znatelný, se umístili výzkumníci a odborníci v oblasti školství. Podobný význam jako akademikům byl ale přisouzen i školním inspektorům. Jejich roli vidí jako "velmi výraznou/výraznou" mezi $60 \%$ a $70 \%$ dotázaných, přičemž valná většina respondentů volí opět méně vyhraněnou odpověd" "výrazně" (kolem $50 \%$ v obou případech). O "velmi výrazné" roli výzkumníků či školských inspekcí je jednoznačně přesvědčeno jen okolo desetiny respondentư ${ }^{5}$.

Mezi aktéry, jejichž vliv na podobu základní školy je naopak chápán jako velmi nízký, patří zejména církve ${ }^{6}$ a odbory, ale poněkud překvapivě také nevládní organizace. Církve pokládá za důležité partnery pro rozvoj školy pouze $8 \%$ dotázaných, odbory a nevládní organizace pak okolo pětiny respondentů. Avšak ani spolupráce či partnerství soukromého a veřejného sektoru není v prípadě primárního a nižšího sekundárního vzdělávacího stupně chápáno jako klíčové a pro budoucí podobu školy rozhodující.

5 V budoucím šetření zvažujeme rozšíritit seznam aktérů např. o ped. fakulty, vydavatele učebnic, média aj.

6 Zde panuje opět vysoký konsenzus, tedy vysoká míra shody mezi dotazovanými (viz směrodatná odchylka). 
Tab. 4. Kdo má největší vliv na podobu školy?

\begin{tabular}{|l|c|c|}
\hline & Průměr & $\begin{array}{c}\text { Směrodatná } \\
\text { odchylka }\end{array}$ \\
\hline Ředitelé škol & 1,2 & 0,48 \\
Učitelé & 1,3 & 0,59 \\
MŠMT & 1,5 & 0,58 \\
Parlament ČR & 1,7 & 0,78 \\
Vláda ČR & 1,8 & 0,77 \\
Zastupitelstva měst a obcí (obecní úřady) & 1,8 & 0,70 \\
Rodiče, případně jejich organizace & 2,0 & 0,63 \\
Žáci sami & 2,0 & 0,68 \\
Krajská samospráva & 2,0 & 0,72 \\
EU & 2,1 & 0,61 \\
Výzkumníci a odborníci v oblasti školství & 2,2 & 0,70 \\
Školní inspekce & 2,2 & 0,71 \\
\hline Soukromá sféra (podniky, zaměstnavatelé) & 2,6 & 0,80 \\
Nevládní organizace & 2,9 & 0,63 \\
Odbory & 3,0 & 0,74 \\
Církve & 3,2 & 0,58 \\
\hline
\end{tabular}

Při orientační komparaci s již provedeným výzkumem veřejného mínění z poloviny 90. let (AMD 1995), který byl zacílen na celou dospělou populaci České republiky, pozorujeme velmi obdobné hodnocení důležitosti jednotlivých aktérů8. Jako nejdůležitější byla chápána role tří aktérů: MŠMT, učitelů a ředitelů škol ( $v$ tomto pořadí). Naopak jako vyloženě negativní byly posuzovány odbory a církve, jejichž vliv na podobu školství byl českou veřejností vnímán jako nežádoucí. Zdá se tedy, že existuje poměrně konzistentní stanovisko ohledně významu jednotlivých subjektů působících v oblasti školství, které je do značné míry shodné jak mezi školským managementem, tak i širokou laickou veřejností. Přitom role ministerstva školství a aktérů působících prímo na úrovni školy je chápána jako naprosto klíčová a nezastupitelná.

7 Respondentům byla ke každému aktérovi přiložena čtyřbodová škála od 1 (může ovlivnit „,velmi výrazně“) až po 4 („rozhodně nemůže vůbec ovlivnit“"). Aktéři, jejichž průměrná hodnota se pohybuje od 1 do 2,5, jsou tedy pokládáni za významně ovlivňující podobu školy. Naopak ti, jejichž průměrná hodnota je větší než 2,5 jsou pokládáni za nevýznamné.

8 Otázka se však netýkala školy, ale celého školského systému, navíc byla položena normativně: „Které instituce by měly rozhodujícím způsobem přispět k rozvoji našeho školství?" Seznam aktérů v tomto výzkumu byl méně rozsáhlý (chyběly NGOs, děti a žáci, Evropská unie aj.). 


\subsection{Já jako aktér změny?}

Mezi respondenty převládá jednoznačně nespokojenost se současným stavem českého školství. Naprostá většina dotázaných školských managerů je „spíše nespokojena" (dvě třetiny). To je v souladu s již realizovanými výzkumy (AMD 1996), kdy skupina ředitelů a učitelů vykázala výraznou kritičnost vůči stavu školství, zatímco široká veřejnost či odborníci a experti z oblasti vzdělávání byli spíše spokojeni.

Většina dotázaných se zároveň domnívá, že nemůže jakkoliv ovlivnit podobu vzdělávacího systému v naší zemi, ačkoliv je s ním sama nespokojena. Na sedmistupňové škále (1="žádný vliv" až 7="naprosto klíčový vliv") je průměrná odpověd" rovna 2,3. Jako realistické hodnocení vlastních možností se ukázalo podstatně vyšší subjektivní ohodnocení vlivu na podobu školy (opět sedmistupňová škála, průměr 4,3). I tak je ale tento vliv chápán jako spíše průměrný (,„ani ano, ani ne“), tedy ve středním pásmu stupnice. To může být ze strany školského managementu chápáno jako poměrně překvapivá odpověd' vyjadřující určitou bezmoc zásadním způsobem formovat podobu školy, na které profesně působí. Je ale nutné uvést, že zatímco učitelé svůj vliv na podobu školy hodnotí jako podprůměrný (průměr $3,4)$, ředitelé jsou si svým vlivem jisti daleko více $(4,8)$ a zástupci ředitelů (!) nejvíce $(5,2)$. Zjednodušeně však Ize učinit nepřiliš optimistický závěr, že školský management není se stavem školství vůbec spokojen, zároveň ale nevidí příliš velkou možnost, že by se situací ve školství, ale i na vlastní škole (!), mohl něco vlastními silami udělat.

\subsection{Klíčové problémy: co limituje rozvoj školy?}

Zde se pokusíme nastínit největší problémy, s nimiž se podle názorů školského managementu potýkají naše základní školy ${ }^{9}$. Jako zdaleka nejtíživější je chápána trojice problémů ( $v$ tomto pořadí): nedůslednost a chaotičnosti při prosazování reforem školství (ze strany MŠMT), šíření drog mezi žáky a bujení násilí a šikany na školách. Mezi respondenty panuje vysoký konsenzus ohledně primátu těchto tř́ problémů (nízká hodnota směrodatné odchylky), prakticky všichni dotázaní tyto jevy hodnotí jako problém, více než dvě třetiny pak jako problém „velmi vážný". Zdá se tedy, že problém deviantního chování, se kterým se potýká naše školství, není jen nadproporčně a selektivně zastoupen v mediálním diskurzu o školství (viz Syřiště 2002), ale že je jako podobně vážný vnímán i aktéry působícími přímo ve vedení škol. Také negativní hodnocení implementace reforem nevrhá dobré světlo na práci či kvalitu komunikace MŠMT (zde se Ize domnívat, že výraznou roli hrálo aktuální dění: zavádění rámcových vzdělávacích programů a vytváření školních vzdělávacích programů na úrovni jednotlivých škol, problémy se zaváděním státních maturit atd.).

9 Respondentům byla nabídnuta baterie 26 problémů, které měli ohodnotit s pomocí 4stupňové škály. Do budoucna uvažuji doplnit o demografické problémy (nízká míra porodnosti - „nedostatek dětíi"). 
Poměrně přetkvapivě nejsou jako nejvážnější chápány často verbalizované a medializované problémy spjaté s nedostatkem financí v resortu školství: nízké platy učitelů byly respondenty rekrutujícími se ze školského managementu ohodnoceny "až" jako 6. nejproblematičtější položka (za "velmi vážný problém“ pokládá třetina respondentů, další polovina za „poměrně vážný"), celkový nedostatek financí jako 9. nejvážnější problém a špatné materiální vybavení dokonce až jako položka 18. (za "velmi vážný problém" pokládá $17 \%$ respondentů).

Jako skutečně bezproblémové se našim respondentům jeví dvě skupiny položek: selektivnost uplatňovaná ve vzdělávání (existence víceletých gymnázií a selekce žáků v nízkém věku - třídy a školy pro talentované, s rozšírenou výukou matematiky, jazyků aj.) a oslabování vlivu státních orgánů na chod školy (nízká úroveň řízení škol ze strany nadřizených orgánů, klesající vliv státních orgánů na chod školy). $\checkmark$ případě rané selekce, která je pokládána za jeden z hlavních faktorů ovlivňujících vznik a reprodukci vzdělanostních nerovností v českém školství (např. Matějü, Straková et al. 2006), je zřejmé, že tento problém není školskými managery s největší pravděpodobností reflektován. Za „velmi vážný" problém pokládá časnou selekci žáků pouze 8 - $9 \%$ dotázaných ${ }^{10}$.

Celkové pořadí závažnosti jednotlivých problémů tak, jak jsou chápány školským managementem, je zobrazeno v tabulce č. 5. Faktorová analýza odhalila sedm hlavních skupin či okruhů problémů tvořených položkami, jež respondenti chápou jako vzájemně si blízké. Byly nazvány takto ( $v$ pořadí podle závažnosti, jež jim přisuzují respondenti) ${ }^{11}: 1$. faktor chaotičnosti reforem ze strany MŠMT (průměr 1,37), 2. faktor deviantního chování žáků $(1,57)$ - šírení drog mezi žáky, násilí a šikana mezi žáky, projevy rasové nesnášenlivosti, 3. faktor finančních zdrojů $(1,93)$ - celkový nedostatek financí, špatné materiální vybavení, nízké platy učitelů, 4. faktor personálních problémů $(1,98)$ - nedostatek mužů v pedagogickém sboru a vysoký počet žáků v jedné třídě, 5 . faktor „zakonzervovanosti“ škol a neschopnosti reagovat na nové výzvy $(2,6)$, který je „sycen“ největším počtem položek - např. zastaralý obsah předmětů, potlačování osobnosti žáka, převaha reprodukce poznatků nad rozvojem klíčových kompetencí, neochota škol inovovat aj., 6. faktor oslabování role státu $(2,68)$ a 7 . faktor rané selekce $(2,91)$.

10 Pokud je pokládáno za problém, Ize předpokládat (ačkoliv jde již o interpretaci „za“ rámec dat), že existence víceletých gymnázií či výběrových škol způsobuje odliv talentovaných žáků z běžných základních škol a takto je raná selekce jako problém chápána jako problém pro některé školy, nikoliv problém související se sociálními nerovnostmi.

11 Nejprve byly s pomocí faktorové analýzy identifikovány položky, které tvoří jednotlivé faktory. Poté byl spočítán aritmetický průměr položek z jednotlivých faktorů. Položky "nedostatek kvalitních učitelů" a "nezájem žáků o výuku“ byly z této analýzy vyloučeny, protože "sytily“ více než jeden faktor (byly respondenty chápány jako nejednoznačné). 
Tab. 5. Problémy základních škol

\begin{tabular}{|l|c|c|c|}
\hline & Průměr & $\begin{array}{c}\text { Směrodatná } \\
\text { odchylka }\end{array}$ & Pořadí \\
\hline $\begin{array}{l}\text { nedůslednost a chaotičnost při prosazování re- } \\
\text { forem školství }\end{array}$ & 1,37 & 0,54 & 1 \\
\hline šíření drog mezi žáky & 1,41 & 0,62 & 2 \\
\hline násilí, šikana mezi žáky & 1,42 & 0,59 & 3 \\
\hline nedostatek kvalitních učitelů & 1,70 & 0,82 & 4 \\
\hline nezájem žáků o výuku & 1,76 & 0,75 & 5 \\
\hline nízké platy učitelů & 1,83 & 0,74 & 6 \\
\hline $\begin{array}{l}\text { převaha reprodukce poznatků nad rozvojem klí- } \\
\text { čových kompetencí }\end{array}$ & 1,84 & 0,72 & 7 \\
\hline přístup učitelů k žákům & 1,84 & 0,90 & 8 \\
\hline celkový nedostatek financí & 1,84 & 0,69 & 9 \\
\hline projevy rasové nesnášenlivosti & 1,87 & 0,81 & 10 \\
\hline nedostatek mužů v pedagogickém sboru & 1,87 & 0,81 & 11 \\
\hline potlačování osobnosti žáka & 1,93 & 0,86 & 12 \\
\hline neschopnost či neochota škol inovovat & 1,96 & 0,78 & 13 \\
\hline nedostatečný rozvoj talentů & 1,97 & 0,79 & 14 \\
\hline nedostatečná péče o slabší žáky & 2,04 & 0,72 & 15 \\
\hline Zastaralý obsah předmětů & 2,07 & 0,89 & 16 \\
\hline příliš vysoký počet žáků v jedné třídě & 2,11 & 0,92 & 17 \\
\hline špatné materiální vybavení & 2,13 & 0,70 & 18 \\
\hline nedobrý příštup k postiženým dětem & 2,15 & 0,94 & 19 \\
\hline Protekce při přijímacím řízení & 2,22 & 0,95 & 20 \\
\hline nespravedlivé hodnocení žáků & 2,27 & 1,00 & 21 \\
\hline necitlivý přístup k žåkům příslušníků minorit & 2,32 & 0,87 & 22 \\
\hline $\begin{array}{l}\text { nízká úroveň řízení škol ze strany nadřízených } \\
\text { orgánů }\end{array}$ & 2,34 & 0,86 & 23 \\
\hline selekce žáků v nízkém věku (výběrové třídy aj.) & 2,80 & 0,93 & 24 \\
\hline klesající vliv státních orgánů na chod školy & 3,03 & 0,87 & 25 \\
\hline existence víceletých gymnázií & 3,03 & 0,97 & 26 \\
\hline
\end{tabular}

(řazeno sestupně; 1 = „velmi vážný problém", 4 = „nepokládám za problém")

Při orientační komparaci názorů školského managementu a veřejného mínění české populace (data jsou z poloviny 90 . let, viz AMD 1995) opět - podobně jako u tématu aktérů - pozorujeme jistou míru shody těchto dvou skupin ${ }^{12}$. Také česká veřejnost pokládá za nejzávažnější problémy týkající se deviantního chování - šírení drog mezi žáky, násilí a šikana mezi žáky či projevy rasové nesnášenlivosti. Jako výrazný problém byl - stejně jako v našem šetření - chápán nedostatek kvalitních

$12 \mathrm{~V}$ tomto šetření byla respondentům předložena $\mathrm{k}$ posouzení baterie s 20 položkami - většina z nich byla obsažena i v našem výzkumu. Otázka se však týkala škol obecně, tedy nikoliv pouze základních škol. 
učitelů, ale jako poněkud výraznější byly hodnoceny problémy spjaté s nedostatkem financí (včetně nízkých platů a nedostatku mužů v pedagogickém sboru). Naopak jako problém není viděn klesající vliv státu na školy.

\section{Vnější a vnitřní trendy ovlivňující podobu školy}

Hovoří se o celé řadě vnějších (týkají se širšího společenského kontextu), ale i vnitřních (na úrovni vzdělávacího sytému) trendů, které mohou mít - přímý či neprímý - vliv na podobu školy a vzdělávání. Šetření jejich percepce ze strany školského managementu bylo součástí našeho výzkumu, přičemž každý z respondentů měl ohodnotit sadu 29 vnějších a 40 vnitřních trendů podle předpokládaného vlivu, který by tento trend mohl mít na podobu vzdělávání v České republice v př́ístích 10 letech. Tyto položky byly převzaty z mezinárodní delfské studie LEONIE, kdy se skupina 92 oslovených expertů snažila jednotlivé - z hlediska budoucnosti vzdělávání klíčové - trendy identifikovat (Kotásek 2004b, LEONIE 2004). Celkově Ize ř́ci, že dopady vnitřních trendů na podobu vzdělávání jsou školskými manažery hodnoceny jako zásadnější (vyšší průměrná hodnota na 7stupňových škálách), patrně proto, že jejich vliv je chápán jako bezprostřednější. Podobné závěry lze vyvodit z delfské studie LEONIE.

\subsection{Vnější trendy}

Tyto celospolečenské změny Ize vysledovat ve čtyřech oblastech: 1. ekonomika - at již v makroekonomickém či mikroekonomickém kontextu, 2. technologie, 3. sociální oblast, 4. politika ${ }^{13}$.

Jako nejvýznamnější se našim respondentům z hlediska budoucnosti školy a vzdělávání jeví tři trendy technologické ( $v$ tomto pořadí): nové a perspektivní možnosti využívání a aplikace ICT, šíření a uplatňování nejnovějších médií (digitální TV, videokonference, digitální publikování, internet aj.) a rozvoj informačně-komunikační infrastruktury (mobilní, bezdrátové, širokopásmové sítě v celoevropském měřítku). Spolu s tím se ale vynořuje obava z růstu nerovností mezi těmi, kdo mají a nemají př́stup k nejnovějším ICT (tzv. digital divide). Ta byla verbalizovaná jako pátý nejvýznamnější trend. Jako významné jsou hodnoceny také socio-kulturní změny: trend k multikulturní společnosti (nárůst minorit, imigrace aj., 7. pozice) a nárůst rozmanitosti životních stylů, hodnotových orientací a subkultur (8. pozice). V sociálně-politické oblasti je chápán jako nejdůležitější trend (4. pozice) k oslabování funkcí sociálního státu ( $v$ oblasti lékařské péče, vzdělávání aj.), všeobecná změna politických programů s rostoucím důrazem na otázky vnitřní i vnější bez-

13 Za vážný nedostatek výzkumu LEONIE pokládám skutečnost, že mezi položkami externích trendů ovlivňujících podobu školy a vzdělávacího systému nebyly zastoupeny změny související s demografickým přechodem (snižování plodnosti a porodnosti, stárnutí obyvatelstva a pracovní síly, rozpad rodiny a zvyšující se rozvodovost) či další okruhy změn (např. vliv médií na socializaci, ekologická krize a trvalá udržitelnost). 
pečnosti (9. pozice) a změna sociální struktury $v$ důsledku polarizace mezi chudnoucí většinou středních vrstev a nejvyššími př́ijmovými kategoriemi (11. pozice). Z ekonomických trendů vidí dotazovaní největší důsledky pro oblast vzdělávání $v$ transformaci směrem $k$ ekonomice založené na znalostech (6. pozice), případně ve zpomalení ekonomického růstu (10. pozice) či trendu k vyšší společenské zodpovědnosti firem (12. pozice).

Ve srovnání s experty (LEONIE 2004) byl mezi našimi respondenty patrný výraznější "technologický determinismus“ (role ICT aj.) a zdůraznění socio-kulturních trendů (multikulturalismus aj.) na úkor „ekonomizujícího“ pohledu expertů. Ti naopak nejvíce zdůrazňovali roli makroekonomických trendů jako je vzestup znalostní ekonomiky a nárůst mezinárodní výměny (1. a 2. pozice) či mikroekonomických změn typu nárůst flexibility (na úrovni jedinců i podniků) a organizační změny uvnitř firem (5. a 10. pozice).

\subsection{Vnitřní trendy}

V tomto případě jde o hodnocení významnosti jednotlivých změn (celkem 40 položek) uvnitř vzdělávacích systémů samotných (endogenní procesy). Ze subjektivně nejvýznamnějších trendů se tři týkají změn v rovině učitelské profese: nárůst dalšího vzdělávání učitelů, vychovatelů a instruktorů (1. pozice), dále úpadek profesního statusu a společenského postavení učitelů a zvýšená fluktuace a odliv učitelů do jiných sektorů či pozic (4. a 5. pozice). Kromě toho byla zdůrazňovaná obava z budoucího snižení objemu veřejných financí určených pro formální vzdělávání (2. pozice). Tyto trendy jsou typické pro krizový scénář budoucnosti školy ${ }^{14}$. Dále byla zdůrazněna rostoucí role celoživotního a dalšího vzdělávání (3. pozice), které souvisí s reflektovanou akcelerací zastarávání znalostí a kompetencí (13. pozice). Jako velmi významný je chápán také trend k menšímu počtu žáků ve třídách (6. pozice) a přesun důrazu od učení orientovaného na učitele $k$ učení orientovanému na žáka (7. místo).

Ve srovnání s experty účastnícími se delfské studie LEONIE je mezi českými školskými manažery patrný silnější důraz na dimenzi učitele - předpokládá se větší růst požadavků vyjádřený v očekávaném nárưstu dalšího vzdělávání, zároveň však i paralelní hrozba krize učitelské profese. Experti naopak zdůrazňovali změny v podobě vzdělávacího systému jako celku. Jejich postoj Ize shrnout takto (podle Kotáska 2004b): 1. dojde k multiplikaci učebních příležitostí, prostorů a materiálů spolu s rozvojem vzdělávacích služeb, 2 . zvýší se integrace vzdělávacích systémů a jejich různých dimenzí (formální-informální vzdělávání, zdělávání-trh práce, propojenost vzdělávání různých stupňů a druhů), 3. převládne paradigma celoživotního učení, 4. výrazněji se uplatní tržní principy (marketizace, konkurence, efektivnost) při zachování úlohy veřejných orgánů.

14 Jedním ze záměrů výzkumu bylo - kromě hrubé deskripce prezentované v tomto článku - analyzovat i vzájemné vztahy mezi jednotlivými otázkami či socio-demografickými identifikátory. Zejména pak zjistit s čím souvisí preference jednotlivých scénářů budoucnosti školy (s jakými trendy, politikami, aktéry, respondenty aj.). 


\section{Vzdělávací politika pro přištích 10 let}

Jako inspirace tohoto tematického okruhu posloužila mezinárodní delfská studie LEONIE (2004) s cílem pokusit se o komparaci názorů respondentů z našeho a uvedeného mezinárodního šetření. Respondenti posuzovali celkem 19 konkrétních vzdělávacích politik a plánovitých strategií, jimiž se vzdělávací systémy vyrovnávají s novými požadavky a očekáváními. Pro každou z nich byli, podobně jako $v$ př́ípadě scénářů, dotazováni na dvě věci: pravděpodobnost a přiměěenost (žádoucnost) daných opatření.

Jako jednoznačně nejpravděpodobnější opatření vzdělávací politiky v přištích letech je chápána pokračující podpora využívání informačních a komunikačních technologií na školách ze strany státu.

Další pravděpodobnou strategií se zdá být tlak na zvyšování kvality vzdělávání a s tím související zavádění evaluace na všech úrovních vzdělávání.

Dalšími trendy chápanými jako spiše mírně pravděpodobné jsou: rozšiřování přístupu ke vzdělávacím příležitostem pro všechny (fyzicky handicapované, socio-kulturně znevýhodňované atp.), dále zdokonalování vzdělávání pedagogických pracovníků i aktérů vzdělávací politiky, položení dưrazu na evropskou dimenzi ve vzdělávání (zejména podpora mobility a vytváření evropské kvalifikační struktury), ale také podpora zvyšování kvalifikací pro společnost vědění a snaha učinit celoživotní učení atraktivnějším.

V jakémsi „indiferentním“ středním pásmu - ani pravděpodobných, ani nepravděpodobných politik - se nachází: strategie k integraci vzdělávacích systémů (např. návaznost a průchodnost jednotlivých vzdělávacích stupňů, navázanost vzdělávání na trh práce, propojování formálního, neformálního a informálního vzdělávání), dále rozvíjení podnikatelských schopností odborným výcvikem a vzděláváním, vzdělávání druhé šance a vazeb mezi formálním a neformálním vzděláváním, poskytování učebních přiležitostí reagující na společenskou poptávku (tzv. .,demandsensitive" systém zohledňující (měnící se) požadavky rodičů, minorit, zaměstnavatelů, nevládních organizací, ale také širší veřejnosti). $V$ neposlední řadě se $v$ tomto pásmu nachází také podpora investic do výzkumu a vývoje, podpora nestátních, soukromých poskytovatelů vzdělávání a konečně také státní podpora vyšší účasti mladých lidí na technickém a prírodovědném vzdělávání.

Jako vyloženě nepravděpodobné se jeví zejména přesun finančních zdrojů ze vzdělávání dětí a mládeže ve prospěch vzdělávání dospělých, ale také přesměrování toků financí od poskytovatelů vzdělávání (tedy škol) směrem k uživatelům vzdělávání (tedy žákům, rodinám). Jako nepravděpodobné se zdají býti také strategie snažící se o podporu nevládních neziskových poskytovatelů vzdělávání (ze strany NGOs a místních občanských iniciativ) nebo snaha učinit učitelské povolání atraktivnější. 
Tab. 6. Hodnocení opatření vzdělávací politiky v príištích 10 letech

\begin{tabular}{|c|c|c|c|c|}
\hline & \multicolumn{2}{|c|}{ Pravděpodobnost } & \multicolumn{2}{|c|}{ Přiměřenost } \\
\hline & $\begin{array}{l}\text { Mana- } \\
\text { gement } \\
2007\end{array}$ & LEONIE & $\begin{array}{l}\text { Mana- } \\
\text { gement } \\
2007\end{array}$ & LEONIE \\
\hline podpora využívání ICT v učebních procesech & 3,5 & 3,29 & 1,2 & 3,10 \\
\hline $\begin{array}{l}\text { zvyšování kvality vzdělávání a zavádění evalu- } \\
\text { ace }\end{array}$ & 3,2 & 3,04 & 1,4 & 2,96 \\
\hline $\begin{array}{l}\text { rozšǐ̌ování prístupu ke vzdělávacím přiležitos- } \\
\text { tem pro všechny }\end{array}$ & 2,8 & 2,94 & 1,6 & 2,91 \\
\hline $\begin{array}{l}\text { zdokonalování vzdělávání pedagogických } \\
\text { pracovníků i aktérů vzdělávací politiky }\end{array}$ & 2,8 & 2,96 & 1,6 & 2,96 \\
\hline $\begin{array}{l}\text { položení důrazu na evropskou dimenzi ve vzdě- } \\
\text { lávání - podpora mobility a vytváření evropské } \\
\text { kvalifikační struktury }\end{array}$ & 2,8 & 2,94 & 1,9 & 2,98 \\
\hline $\begin{array}{l}\text { podpora zvyšování kvalifikací pro společnost } \\
\text { vědění }\end{array}$ & 2,8 & 2,96 & 1,8 & 3,00 \\
\hline snaha učinit celoživotní učení atraktivnějším & 2,7 & 2,98 & 1,6 & 2,79 \\
\hline $\begin{array}{l}\text { strategie k integraci vzdělávacích systémů } \\
\text { (např. návaznost vzdělávání, trhu práce a širší } \\
\text { společnosti, vztah mezi formálním a informál- } \\
\text { ním vzděláváním) }\end{array}$ & 2,6 & 2,85 & 1,7 & 2,81 \\
\hline $\begin{array}{l}\text { rozvíjení podnikatelských schopností odbor- } \\
\text { ným výcvikem a vzděláváním }\end{array}$ & 2,6 & 2,88 & 1,7 & 2,78 \\
\hline $\begin{array}{l}\text { rozvíjení vzdělávání druhé šance a vazeb mezi } \\
\text { formálním a neformálním vzděláváním }\end{array}$ & 2,6 & 2,71 & 1,8 & 2,82 \\
\hline $\begin{array}{l}\text { poskytování učebních př́ležitostí dle sociální } \\
\text { poptávky (veřejnosti, rodičů, firem, NGOs aj.) }\end{array}$ & 2,5 & 2,75 & 1,9 & 2,79 \\
\hline podpora investic do výzkumu a vývoje & 2,4 & 2,83 & 1,7 & 3,26 \\
\hline $\begin{array}{l}\text { podpora vzniku a upevňování soukromých } \\
\text { poskytovatelů vzdělávání (např. podnikového } \\
\text { vzdělávání) }\end{array}$ & 2,4 & 2,94 & 2,3 & 2,63 \\
\hline $\begin{array}{l}\text { podpora účasti (počtu studentů) na prírodo- } \\
\text { vědném a technickém vzdělávání }\end{array}$ & 2,3 & 3,01 & 1,9 & 3,05 \\
\hline snaha učinit učitelské povolání atraktivnějším & 2,1 & 2,98 & 1,7 & 2,79 \\
\hline $\begin{array}{l}\text { snižování nákladů prostřednictvím zvyšování } \\
\text { produktivity vzdělávání }\end{array}$ & 2,1 & 2,81 & 2,1 & 2,71 \\
\hline $\begin{array}{l}\text { podpora neziskových poskytovatelů vzdělávání } \\
\text { (lokální iniciativy, NGOs) }\end{array}$ & 2,0 & 2,84 & 2,4 & 2,76 \\
\hline $\begin{array}{l}\text { přesun financí od poskytovatelů (školy) na } \\
\text { jejich uživatele (např. žáky) }\end{array}$ & 2,0 & 2,69 & 2,6 & 2,76 \\
\hline $\begin{array}{l}\text { přesun financí ze vzdělávání dětí a mládeže na } \\
\text { vzdělávání dospělých }\end{array}$ & 1,8 & 2,58 & 2,8 & 2,37 \\
\hline
\end{tabular}


Pozitivním zjištěním je skutečnosti, že existuje silný statistický vztah (korelační koeficient 0,83 ) mezi percepcí pravděpodobných/očekávaných politik a těch strategií, jež respondenti hodnotí jako ideální či žádoucí. Jinými slovy očekávaný reálný vývoj státní vzdělávací politiky je do značné míry v souladu s tím, co by podle nich bylo žádoucí. Při bližším pohledu vidíme, že jako nejvíce žádoucí respondenti pokládají podporu využívání ICT v učebních procesech, zvyšování kvality, zlepšování vzdělávání pedagogů i aktérů vzdělávací politiky a rozšiřování přístupu ke vzdělanostním přiležitostem pro všechny. Toto pořadí se shoduje s hodnocením pravděpodobně očekávaných politik, avšak dotazovaní by se přimlouvali také o větší snahu učinit učitelské povolání atraktivnějším, což ale zároveň nepokládají za pravděpodobné opatření vzdělávací politiky přištích 10 let. Na druhém pólu - spíše nežádoucích opatření vzdělávací politiky - se nalézají tato opatření: podpora neziskových poskytovatelů vzdělávání (NGOs aj.), přesun financí od poskytovatelů na jejich klienty (žáky) a zejména přesun financí ze vzdělávání dětí a mládeže na vzdělávání dospělých.

Srovnání s mezinárodním výzkumem LEONIE, který se opírá o názory expertů (tedy jde opět o poněkud jinou, i když také silně zainteresovanou sociální skupinu) z 8 evropských zemí (podrobně Kotásek 2004b) umožní jen orientační komparaci a nastínění základních shodných či rozdílných tendencí. Pokud jde o pravděpodobné trendy, také $v$ mezinárodním šetření LEONIE bylo jako nejreálnější viděno: podpora využívání ICT v učebních procesech a zvyšování kvality vzdělávání a zavádění evaluace. To je ve shodě s naším šetřením, podobně jako hodnocení nejméně pravděpodobných politik: přesunu zdrojů ze vzdělávání dětí a mládeže do oblasti vzdělávání dospělých. Avšak na třetím a čtvrtém místě se z hlediska pravděpodobnosti umístila podpora účasti na prírodovědném a technickém vzdělávání a snaha učinit učitelské povolání atraktivnější, což jsou politické strategie, které u našich respondentů nebyly pokládány za př́liš pravděpodobné.

Ještě výraznější inkonsistence byla zjištěna v prípadě hodnocení žádoucích/ideálních opatření vzdělávací politiky. Experti pokládají za nejpřiměřenější opatření podporu investic do výzkumu a vývoje a až poté podporu využívání ICT či podporu zvyšování účasti na přírodovědném a technickém vzdělávání následovanou snahou učinit celoživotní učení atraktivnějším.

\section{Závěry}

Na tomto místě zrekapitulujme a shrňme hlavní výzkumné nálezy týkající se percepce budoucnosti školy a školního vzdělávání.

Pokud jde o institucionální podobu školy v 21. století, mezi respondenty z řad školského managementu panuje vysoká nejistota ohledně směřování budoucího vývoje - jako mírně pravděpodobnější je chápána skupina rescholarizačních scénářư (modely komunitní a učící se školy). Alarmující je však zjištění, že celých 55 \% respondentů se obává krizového scénáře vývoje souvisejícího s odlivem lidí z učitelské profese. Jako spíše nepravděpodobné se jeví jak scénář tržní, tak i model školy založený na sítích učících se v podmínkách společnosti sítí. 
Jestliže respondenti mají problém ohodnotit pravděpodobnou podobu školy budoucnosti, panuje mezi nimi vysoká míra jistoty i konsenzu ohledně toho, jak by taková škola měla v ideálním případě vypadat. Jasným „favoritem“ jsou rescholarizační modely školy: modely komunitní a učící se školy. Za jasného "outsidera" je naopak považován tradiční byrokratický model školy, tedy ten, který je svou podobou nejbližší současnému stavu.

Jaké znalosti, dovednosti, postoje a hodnoty by měla škola budoucnosti rozvíjet? Jde zejména o tyto faktory: 1. faktor základů pro další studium (naučit se učit - kompetence k řizení vlastního učení, umět logicky myslet, být samostatný a umět se rozhodovat, 2 . chut' a motivace do dalšího studia (faktor tvořený jedinou položkou), 3. faktor etických postojů a morálního usuzování: rozvoj etických postojů a morálního usuzování, kladný postoj k české historii, národu a jeho hodnotám, výchova pro trvale udržitelný rozvoj (ekologická výchova) a 4. faktor slušného chování a dobrého občanství: zdvořilost, slušné chování, být dobrým občanem (zodpovědnost za věci veřejné). Nejmenší důraz byl naopak kladen na znalosti a dovednosti těsně spjaté s konkrétními vyučovacími předměty.

Respondenti rekrutující se z řad školského managementu se domnívají, že největší měrou mohou ovlivnit podobu základní školy a přispět k jejímu rozvoji právě ředitelé škol. Jako podobně významní jsou chápání také učitelé (tj. pedagogický sbor) - jde tedy o aktéry působící prímo na mikroúrovni školy. Jako velmi významné jsou chápány také státní (makro)instituce ovlivňující a určující širší ráme, v němž je škola zasazena (MŠMT, dále parlament a vláda). Naopak výzkumníci a experti působící v oblasti školství, ale i školní inspektoři, jsou chápáni jako „průměrně“ důležití. Církve, odbory, avšak překvapivě také nevládní organizace, jsou hodnoceni jako absolutně nedůležití a bez vlivu na budoucí směřování škol.

Pokud jde o hlavní problémy limitující další rozvoj školy, jsou respondenti zajedno $v$ tom, že bezkonkurenčně největším problémem je nedůslednost a chaotičnost při prosazování reforem školství ze strany MŠMT. Dále jsou jako výrazný problém chápány kázeňské problémy žáků související s deviantním chováním (šíření drog mezi žáky, násilí a šikana mezi žáky, projevy rasové nesnášenlivosti). Teprve poté následují problémy spjaté s nedostatkem finančních zdrojů. Ředitelé naopak nevidí nejmenší problém v rané selekci žáků typické pro české školství a produkující relativně vysokou míru vzdělanostních nerovností (viz selekce žáků v nízkém věku do výběrových tř́id, existence víceletých gymnázií).

Z externích trendů s možným prímým či nepřímým vlivem na budoucí podobu školy a vzdělávání byl zdůrazněn hlavně vliv změn v oblasti nových technologií. Spolu s tím se ale objevuje také obava z růstu sociálních nerovností mezi těmi, kdo mají a nemají přístup $\mathrm{k}$ nejnovějším informačním a komunikačním technologiím (tzv. digital divide). Dále byl zdůrazněn také trend k oslabování funkcí sociálního státu či jeho krize, transformace hospodářství směrem k ekonomice založené na znalostech a trend k multikulturní realitě.

Pokud jde o hodnocení významnosti trendů uvnitř vzdělávacích systémů, největší důležitost ředitelé škol přisuzují změnám týkajícím se učitelské profese: nárůst dalšího vzdělávání učitelů, vychovatelů a instruktorů, dále úpadek profesního 
statusu a společenské prestiže učitelů a také zvýšená fluktuace a odliv učitelů do jiných sektorů. Zdůrazněna byla také obava z budoucího snížení objemu veřejných financí určených pro formální vzdělávání (jde tedy celkově o trendy typické pro krizový scénář školy).

Vzdělávací politiku, kterou respondenti chápou jako žádoucí (tedy ideální), hodnotí zároveň také jako vysoce pravděpodobnou pro přištích 10 let. Jako nejpravděpodobnější vidí další podporu využívání ICT na školách a také tlak na zvyšování kvality vzdělávání a s tím související zavádění evaluace na všech úrovních vzdělávání.

\section{Literatura}

AMD, 1995. Vztah veřejnosti k otázkám školství.

AMD, 1996. Vztah odborníků k otázkám školství.

GREGER, D. Současné trendy vývoje všeobecného vzdělávání. In KALOUS (ed.) Vybrané problémy vzdělávací politiky. Praha : Karolinum, 2006, s. 39-50.

HUTMACHER, W. Visions of Decision-makers and Educators for the Future of Schools: Reactions to the OECD Scenarios. In OECD What Schools for the Future? Paris : OECD, 2001, s. 231-240.

KOTÁSEK, J. Modely školy budoucnosti. In WALTEROVÁ, E. (ed.) Rozvoj národní vzdělanosti a vzdělávání učitelů v evropském kontextu. 1. díl. Teoretické a komparativní studie. Praha : PedF UK, 2002, s. 8-24.

KOTÁSEK, J. Budoucnost školy a vzdělávání. In WALTEROVÁ, E. (ed.) Úloha školy v rozvoji vzdělanosti. Brno : Paido, 2004a, s. 441-484.

KOTÁSEK, J. Zpráva ze zahraniční služební cesty v rakouském Kremsu (pořádající Institut fur Hohere Studien). Praha : ÚVRŠ-PedF UK, 2004b.

LEONIE. Learning in Europe. Observatory on National and International Evolution. Leonie Delphi survey. Final Report. Scienter, 2004.

MATĚJŮ, P.; STRAKOVÁ, J. (ed.) (Ne)Rovné šance na vzdělání. Vzdělanostní nerovnosti $\checkmark$ České republice. Praha: Academia, 2006.

NEKOLOVÁ, M. Scénáře. In POTŮČEK, M. (ed.) Manuál prognostických metod. Praha : SLON, 2006, s. 173-179.

SYŘIŠTĚ, I. Podstata diskurzu o národní vzdělanosti v českých médiích. In Rozvoj národní vzdělanosti a vzdělávání učitelů v evropském kontextu. Praha : PedF UK, 2002, s. 222-235.

What schools for the Future? Paris : OECD, 2001. 